\begin{tabular}{|l|l|l|}
\hline \multicolumn{2}{|c|}{ PublisherInfo } \\
\hline \hline PublisherName & $:$ & BioMed Central \\
\hline \hline PublisherLocation & $:$ & London \\
\hline \hline PublisherImprintName & $:$ & BioMed Central \\
\hline \hline
\end{tabular}

\title{
Articles selected by Faculty of 1000: identifying cereal cell wall biosynthetic genes; unspecific knockdown by RNAi; protoemics of lipid rafts; mating-type gene in asexual fungus; genomic identification of hyperthermophiles
}

\begin{tabular}{|l|l|l||}
\hline \multicolumn{2}{|c||}{ ArticleInfo } \\
\hline \hline ArticleID & $:$ & 3466 \\
\hline \hline ArticleDOI & $:$ & $10.1186 /$ gb-2003-4-7-329 \\
\hline \hline ArticleCitationID & $:$ & 329 \\
\hline \hline ArticleSequenceNumber & $:$ & 14 \\
\hline \hline ArticleCategory & $:$ & Paper report \\
\hline \hline ArticleFirstPage & $:$ & 1 \\
\hline \hline ArticleLastPage & $:$ & 3 \\
\hline \hline & $:$ & RegistrationDate : 2003-6-4 \\
ArticleHistory & $:$ & OnlineDate $\quad$ 2003-6-4 \\
\hline
\end{tabular}




\begin{tabular}{|l||l|l||}
\hline ArticleCopyright & $:$ & BioMed Central Ltd2003 \\
\hline \hline ArticleGrants & $:$ & \\
\hline \hline ArticleContext & $:$ & 130594477 \\
\hline
\end{tabular}

The Author(s)

\section{Summary}

A selection of evaluations from Faculty of $\mathbf{1 0 0 0}$ covering the identification of cereal cell wall biosynthetic genes, off-target gene regulation by RNAi, protoemics of lipid rafts, a mating-type gene in Aspergillus fumigatus and genomic identification of hyperthermophiles.

\section{Identifying cereal cell wall biosynthetic genes}

Quantitative trait loci and comparative genomics of cereal cell wall composition. Hazen SP, Hawley RM, Henrissat B, Walton JD. Plant Physiology 2003, 132:263-271.

For the Faculty of 1000 evaluation of this article please see: http://genomebiology.com/reports/F1000/ gb-2003-4-7-329.asp\#Hazen

\section{Unspecific knockdown by RNAi}

Expression profiling reveals off-target gene regulation by RNAi. Jackson AL, Bartz SR, Schelter J, Kobayashi SV, Burchard J, Mao M, Li B, Cavet G, Linsley PS. Nat Biotechnol 2003, 21:635-637.

For the Faculty of 1000 evaluation of this article please see: http://genomebiology.com/reports/F1000/ gb-2003-4-7-329.asp\#Jackson

\section{Protoemics of lipid rafts}

Unbiased quantitative proteomics of lipid rafts reveals high specificity for signaling factors. Foster LJ, De Hoog CL, Mann M. Proc Natl Acad Sci USA 2003, 100:5813-5818. 
For the Faculty of 1000 evaluation of this article please see: http://genomebiology.com/reports/F1000/ gb-2003-4-7-329.asp\#Foster

\section{Mating-type gene in asexual fungus}

Mating type gene homologues in Aspergillus fumigatus . Varga J. Microbiology 2003, 149:816-819.

For the Faculty of 1000 evaluation of this article please see: http://genomebiology.com/reports/F1000/ gb-2003-4-7-329.asp\#Varga

\section{Genomic identification of hyperthermophiles}

Genomic correlates of hyperthermostability, an update. Suhre K, Claverie JM. J Biol Chem 2003, 278:17198-17202.

For the Faculty of 1000 evaluation of this article please see: http://genomebiology.com/reports/F1000/ gb-2003-4-7-329.asp\#Suhre

This PDF file was created after publication. 